DOI:

УДК 621.865 .8

T.В. Москальова, к.т.н., доцент, moskalova.t.v@nmu.one

М.В. Полушина, к.т.н., доцент, polushina.m.v@nmu.one

А.В. Касьянова, студентка, kasianova.a.v@nmu.one

Національний технічний університет «Дніпровська політехніка», м. Дніпро

\title{
МОДЕЛЮВАННЯ РОБОТИ КОВША ГІДРАВЛІЧНОГО СОТРУВАЛЬНОГО ГРЕЙФЕРА
}

В статті проаналізовано конструкиію грейфера гідравлічного сортувального, також проведено моделювання руху його щелеп. Проведено кінематичний та силовий аналіз конструкиії ковша грейфера. Метою моделювання є підвищення експлуатаційних характеристик грейфера за рахунок збільшення корисного об'єму ковща та усунення недоліків існуючої конструкиї.

Ключові слова: гідравлічний грейфер; щелепа; ковщ; будівельне сміття.

The article considers the design and principle of operation of the sorting hydraulic grab bucket. Kinematic and force analysis of the grab bucket design was performed. The aim of modeling is to increase the operational productivity of the grab by increasing the usable volume of the bucket and eliminating the imperfection of the existing design.

Key words: hydraulic grab; bucket; jaw; sorting; construction waste.

Спектр задач, які виконують сортувальними грейферами є досить широким. Основним завданням $€$ переміщення різних вантажів, серед яких $€$ камінь, грунт, пісок, предмети, що відрізняються формою, ступенем твердості. До основних операцій також відносять засипання i виїмку грунту.

Грейфери - це вантажозахватний пристрій, його застосовують в різних галузях промисловості, наприклад на будівництві, промислових підприємствах, при переробці корисних копалин, при добуванні корисних копалин, на кар'єрах та ін.

\section{Постановка проблеми}

При експлуатації гідравлічного сортувального грейфера виявлено деякі недоліки конструкції: викривлення опори щелепи та вушок що держать гідроциліндр; тріщини в зварювальних швах. Наявні деформації конструкції унеможливлюють подальшу справну роботу ковша. Задля виявлення причин отриманих пошкоджень необхідно провести моделювання та аналіз роботи ковша грейфера.

\section{Аналіз останніх досліджень та публікацій}

Більшість публікацій 3 даної проблеми $[1,2]$ присвячена питанням синтезу та аналізу ефективності важільних механізмів. Аналіз конструкції щелеп ковша грейфера для заготівлі лісу, ефективність його роботи аналізуються в роботах [3-4]. Питання міцності конструкції грейферного екскаватора в цілому присвячена низка робіт [5-8]. Для виявлення причин появлення викривлення та тріщин в конструкції гідравлічного ковша сортувального грейфера необхідно побудувати модель та проаналізувати напружено-деформований стан саме конструкції ковша під дією робочого навантаження, що $є$ актуальною науковою задачею.

\section{Формулювання мети дослідження}

Метою роботи є виявлення причин та методів усунення недоліків металоконструкції ковша грейфера гідравлічного сортувального шляхом аналізу напружено-деформованого стану під дією робочих навантажень.

\section{Виклад основного матеріалу}

Використання сортувальних грейферів пов'язано 3 великими навантаженнями на його конструкцію. Найбільш навантаженими $є$ щелепи грейфера, які саме контактують 3 вантажем при операціях захоплення або зачерпування, в залежності від типу вантажу. На щелепи ковша також діє робоче навантаження від привідних механізмів. 
Як відомо, вантажопідйомність грейфера залежить від ваги самого вантажопідйомного пристрою та його об’єму. При черпанні та переміщенні вантажу можливі різні варіанти розташування матеріалів, нерівномірний розподіл маси вантажу, зміна орієнтації ковша в просторі, що обумовлює різні варіанти навантаження металоконструкції.

Найчастіше грейфери для сортувальних цілей використовують на екскаваторах вагою від 1 до 40 тон. Також їх використовують як складову спеціальної техніки. Гідравлічні грейфери, що виконують сортувальні функції є досить затребуваними від будівельних та промислових підприємств.
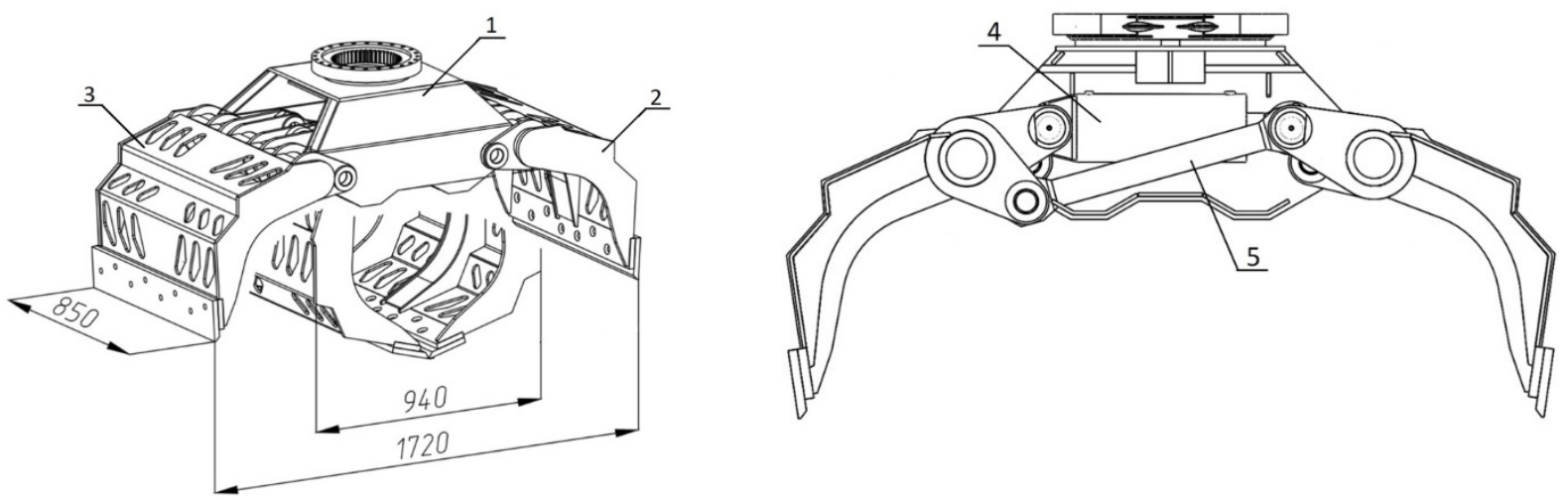

Рuc. 1. Ковш двощелепного грейфера

1 - корпус, 2 - щелепа ліва, 3 - щелепа права, 4 - гідроциліндр, 5 - важіль

Основні складові гідравлічного грейфера наведено на рис. 1. Розкриття щелеп відбувається під дією гідроциліндри при висуванні штоку при поданні робочої рідини під тиском в поршневу порожнину. Процес замикання (закриття) щелеп відбувається при подачі робочої рідини гідроциліндру в штокову порожнину. Зусилля від гідроциліндру перерозподіляється на обидві щелепи через важіль 5, який також вирівнює зусилля між щелепами та унеможливлює мимовільне розкриття щелеп ковша під дією вантажу.

Ковш гідравлічного грейфера оснащений двома захоплюючими елементами - щелепами. Кожна щелепа має бокові стінки 1, опору 2, вушка 3 , посилення 4, плиту 5, обв 'язку 6, ребра 7, розпірку 8, змінний ніж 9 (рис. 2).

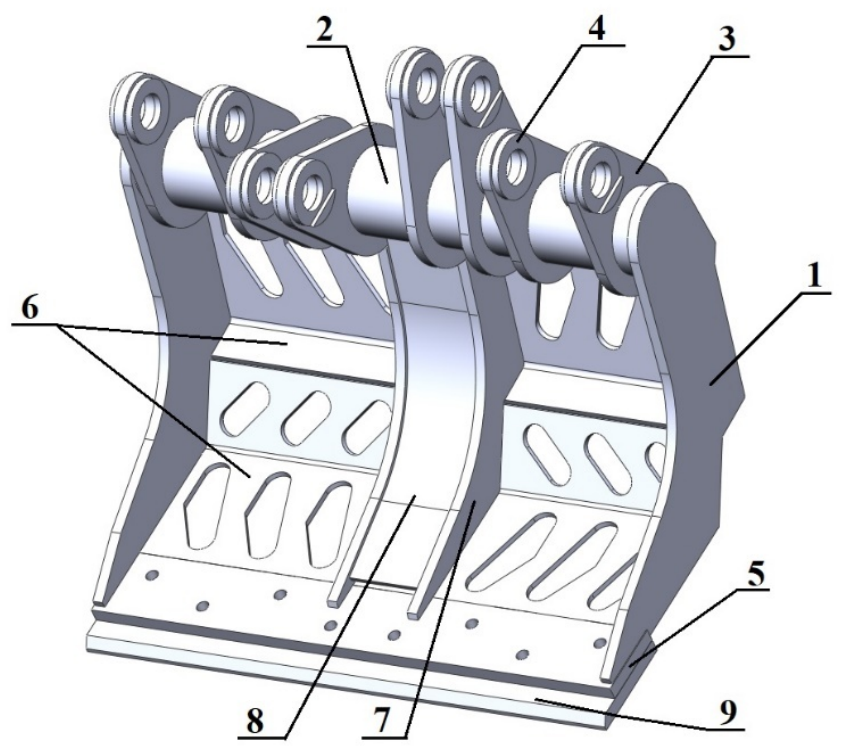

Рuc. 2. Конструкція щелепи ковша сортувального грейфера 
Кожна щелепа ковша грейфера шарнірно з'єднана з корпусом грейфера, гідроциліндром та важелем. Це з'єднання забезпечено наявністю в конструкції щелеп вушок 3 , та посилень 4, які сприймають великі навантаження від маси всього ковша і захопленого матеріалу. Вушка приварюються до опори 2.

Під час захоплення будівельного сміття кожна щелепа ковша грейфера ковзає плитою 5 та обв'язкою 6 по захопленому матеріалу. Обв'язка складається з двох частин зварених між собою, які мають вигнуту форму та вирізи для полегшення конструкції, такої форми, що не дозволяє захопленому матеріалу висипатись. Також захоплення і утримання матеріалу забезпечують стінки 1.

Надійність конструкції кожної щелепи забезпечує наявність ребер 7 та розпірки 8 між ними. Кожна щелепа ковша грейфера оснащена змінним ножем 9, який завдяки болтовому з'єднанню приєднується до щелепи.

Проведемо аналіз руху елементів грейфера під дією гідроциліндру. Для цього побудуємо спрощену схему [4-6], в якій виконаємо заміну реальних вузлів, що можуть рухатися відповідними ланками, розглядаючи їх як абсолютно тверді стрижні (рис. 3).

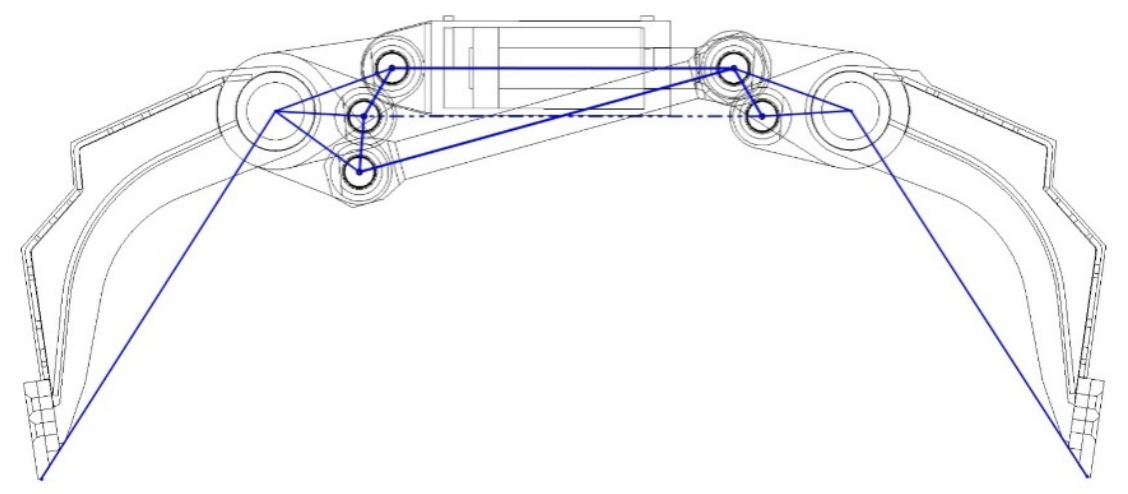

Рис. 3. Побудова схеми грейферного механізму

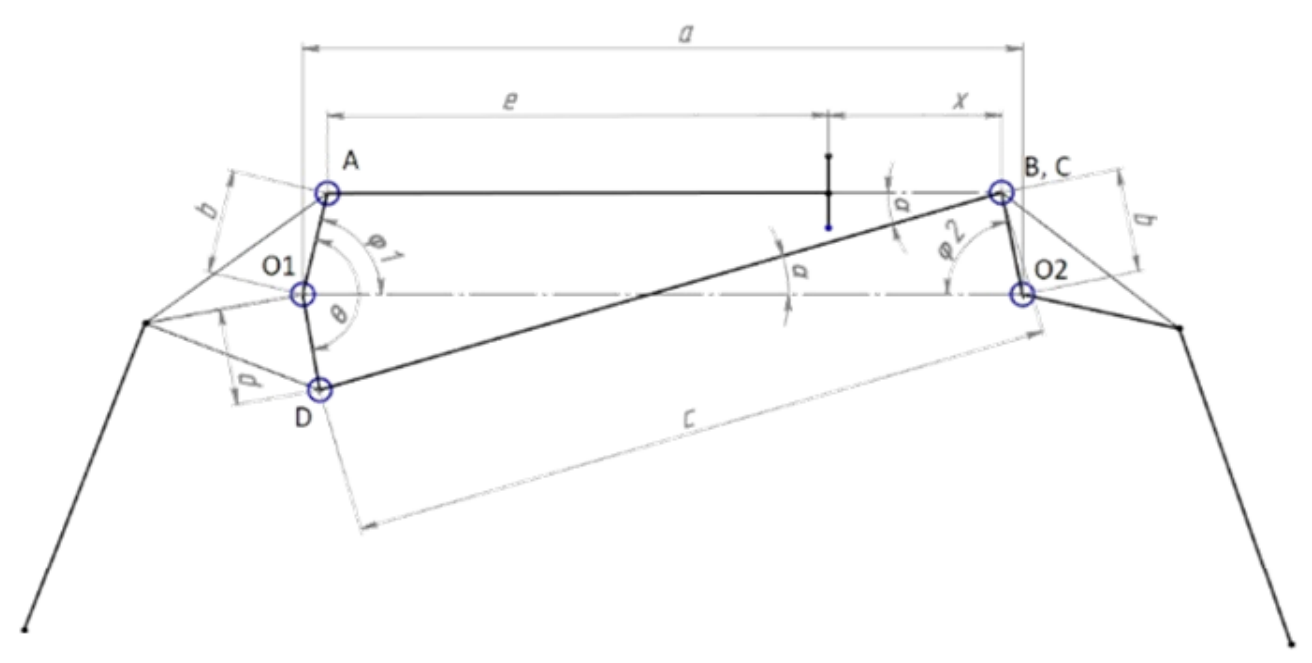

Рuc. 4. Схема грейферного механізму

На рис. 4 наведено спрощену схему грейферного механізму. Розташування нерухомих осей підвісу щелеп до корпуса зазначимо точками $O 1$ і $O 2$. Відстань $O 1$ і $O 2$ незмінна, зазначимо її як $a$. Рух щелеп грейфера відбувається за допомогою штока гідроциліндра 1 , який далі моделюємо стрижнем довжиною $е$. Шток гідроциліндра рухається поступально та змінює відстань $x$. Кріплення гідроциліндру 2 з щелепами 4 та $3 €$ шарнірним, положення осей з'єднання зазна- 
чено точками $A$ та $B$ відповідно. Важіль 5 моделюється стрижнем довжиною $c$ та шарнірно поєднаний з щелепами 4 та 3 , положення осей з'єднання зазначено точками $C$ і $D$. Відстань $O 1 A$ та $O 2 B$ між віссю підвісу щелепи та віссю шарнірного поєднання гідроциліндру з щелепою зазначимо як $b$. Для лівої та правої щелепи ця відстань $є$ однаковою, відповідну конструкцію будемо моделювати жорстким стрижнем. Аналогічно О1D відстань між віссю підвісу та віссю шарнірного кріплення важеля зазначимо літерою $d$. Кріплення важеля на щелепі також характеризується кутом $\theta$.

Рух штока гідроциліндра змінює відстань $x$ та призводить до обертання щелепи 3 відносно осі підвісу $O 1$, та щелепи 2 відносно осі підвісу О2, змінюючи кути положення щелеп $\varphi_{1}$ та $\varphi_{2}$. Одночасно змінюється і позиція важеля 5 , кут нахилу якого зазначимо як $\alpha$.

Моделювання було проведено для грейфера з наступними параметрами: $a=615$ мм; $b=90 \mathrm{мм} ; c=610 \mathrm{мм} ; d=96 \mathrm{мм} ; e=430 \mathrm{мм} ; x=0 \div 200 \mathrm{мм} ; ; \theta=160^{\circ}$.

Проаналізуємо як змінюються значення кутових переміщень $\varphi_{1}$ та $\varphi_{2}$ щелеп ковша грейфера від переміщень штока гідроциліндра, які характеризуються координатою $x$. Спроектуємо довжини ланок грейфера на горизонтальну вісь, що збігається з відрізком $O 1 O 2$. Отримаємо систему рівнянь:

$$
\left\{\begin{array}{c}
b \cdot \cos \varphi_{1}+b \cdot \cos \varphi_{2}+e+x=a, \\
b \cdot \cos \varphi_{2}+d \cdot \cos \left(\theta-\varphi_{1}\right)+c \cdot \cos \alpha=a .
\end{array}\right.
$$

Обчисливши дану систему, отримано значення $\varphi_{1}$ i $\varphi_{2}$. Для цього знайдемо відстань $A D$ за теоремою косинусів:

$$
A D=K=\sqrt{b^{2}+d^{2}-2 \cdot b \cdot d \cdot \cos \theta} .
$$

Із трикутника $\triangle \mathrm{ABD}$ за теоремою косинусів отримаємо:

$$
K^{2}=c^{2}+(e+x)^{2}-2 \cdot c \cdot(e+x) \cdot \cos \alpha .
$$

Тоді кут нахилу важеля до горизонту можна виразити:

$$
\cos \alpha=\left((e+x)^{\wedge} 2+c^{\wedge} 2-b^{\wedge} 2-d^{\wedge} 2+2 \cdot b \cdot d \cdot \cos \theta\right) /(2 \cdot c \cdot(e+x)) .
$$

Підставимо отриманий вираз $\cos (\alpha)$ в друге рівняння системи $(1)$ :

$$
b \cdot \cos \varphi_{2}+d \cdot \cos \left(\theta-\varphi_{1}\right)+\frac{(e+x)^{2}+c^{2}-b^{2}-d^{2}+2 \cdot b \cdot d \cdot \cos \theta}{2 \cdot(e+x)}=a .
$$

Далі знайдемо вираз $b \cdot \cos \varphi_{2}$ :

$$
b \cdot \cos \varphi_{2}=\mathrm{a}-d \cdot \cos \left(\theta-\varphi_{1}\right)-\frac{(e+x)^{2}+c^{2}-b^{2}-d^{2}+2 \cdot b \cdot d \cdot \cos \theta}{2 \cdot(e+x)} .
$$

Після підстановки до системи (1) отримаємо:

$$
b \cdot \cos \varphi_{1}+a-d \cdot \cos \left(\theta-\varphi_{1}\right)-\frac{(e+x)^{2}+c^{2}-b^{2}-d^{2}+2 \cdot b \cdot d \cdot \cos \theta}{2 \cdot(e+x)}+e+x=a .
$$

Спростимо останнє рівняння і запишемо:

$$
\begin{gathered}
b \cdot \cos \varphi_{1}-d \cdot \cos \theta \cdot \cos \varphi_{1}-d \cdot \sin \theta \cdot \sin \varphi_{1}+e+x- \\
-\frac{(e+x)^{2}+c^{2}-b^{2}-d^{2}+2 \cdot b \cdot d \cdot \cos \theta}{2 \cdot(e+x)}=0 .
\end{gathered}
$$

Розв'яжемо рівняння (2) і знайдемо $\cos \varphi_{1}$. Для цього виразимо $\sin \varphi_{1}$ через $\cos \varphi_{1}$ :

$$
(b-d \cdot \cos \theta) \cdot \cos \varphi_{1}+e+x-\frac{(e+x)^{2}+c^{2}-b^{2}-d^{2}+2 \cdot b \cdot d \cdot \cos \theta}{2 \cdot(e+x)}=d \cdot \sin \theta \cdot \sin \varphi_{1} .
$$

Підставимо вираз (4) у рівняння (3):

та отримаймо

$$
\sin \varphi_{1}=\sqrt{1-\cos \varphi_{1}^{2}}
$$




$$
\begin{aligned}
& (b-d \cdot \cos \theta) \cdot \cos \varphi_{1}+e+x-\frac{(e+x)^{2}+c^{2}-b^{2}-d^{2}+2 \cdot b \cdot d \cdot \cos \theta}{2 \cdot(e+x)}= \\
& \quad=\mathrm{d} \cdot \sin \theta \cdot \sqrt{1-\cos \varphi_{1}{ }^{2}} .
\end{aligned}
$$

Піднесемо обидві частини (5) до квадрату:

$$
\begin{gathered}
(b-d \cdot \cos \theta)^{2} \cdot \cos \varphi_{1}{ }^{2}+ \\
+2(b-d \cdot \cos \theta)\left[e+x-\frac{(e+x)^{2}+c^{2}-b^{2}-d^{2}+2 \cdot b \cdot d \cdot \cos \theta}{2 \cdot(e+x)}\right] \cos \varphi_{1}+ \\
+\left[e+x-\frac{(e+x)^{2}+c^{2}-b^{2}-d^{2}+2 \cdot b \cdot d \cdot \cos \theta}{2 \cdot(e+x)}\right]^{2}=d^{2} \cdot \sin \theta^{2} \cdot\left(1-\cos \varphi_{1}{ }^{2}\right) .
\end{gathered}
$$

Після математичних перетворень отримаємо:

$$
\begin{gathered}
{\left[(\mathrm{b}-\mathrm{d} \cdot \cos \theta)^{2}+d^{2} \cdot \sin \theta^{2}\right] \cdot \cos \varphi_{1}^{2}+} \\
+2(\mathrm{~b}-\mathrm{d} \cdot \cos \theta)\left[e+x-\frac{(e+x)^{2}+c^{2}-b^{2}-d^{2}+2 \cdot b \cdot d \cdot \cos \theta}{2 \cdot(e+x)}\right] \cos \varphi_{1}- \\
-d^{2} \cdot \sin \theta^{2}+\left[e+x-\frac{(e+x)^{2}+c^{2}-b^{2}-d^{2}+2 \cdot b \cdot d \cdot \cos \theta}{2 \cdot(e+x)}\right]^{2}=0
\end{gathered}
$$

Введемо нові змінні та запишемо їх в систему рівнянь:

$$
\left\{\begin{array}{c}
\mathrm{A}=(\mathrm{b}-\mathrm{d} \cdot \cos \theta)^{2}+d^{2} \cdot \sin \theta^{2} \\
\mathrm{~B}=2(\mathrm{~b}-\mathrm{d} \cdot \cos \theta)\left[e+x-\frac{(e+x)^{2}+c^{2}-b^{2}-d^{2}+2 \cdot b \cdot d \cdot \cos \theta}{2 \cdot(e+x)}\right] \\
\mathrm{C}=\left[e+x-\frac{(e+x)^{2}+c^{2}-b^{2}-d^{2}+2 \cdot b \cdot d \cdot \cos \theta}{2 \cdot(e+x)}\right]^{2}-d^{2} \cdot \sin \theta^{2} \\
\mathrm{~A} \cdot \cos \varphi_{1}{ }^{2}+\mathrm{B} \cdot \cos \varphi_{1}+\mathrm{C}=0
\end{array}\right.
$$

3 останнього рівняння системи (6) знайдемо $\cos \varphi_{1}$ :

Звідки $\varphi_{1}$ :

$$
\cos \varphi_{1}=\frac{-\mathrm{B}-\sqrt{\mathrm{B}^{2}-4 \mathrm{~A} \cdot \mathrm{C}}}{2 \mathrm{~A}}
$$

$$
\varphi_{1}=\arccos \left(\frac{-\mathrm{B}-\sqrt{\mathrm{B}^{2}-4 \mathrm{~A} \cdot \mathrm{C}}}{2 \mathrm{~A}}\right) .
$$

Для знаходження $\cos \varphi_{2}$ запишемо:

$$
\cos \varphi_{2}=\frac{1}{b}\left[a-d \cdot \cos \left(\theta-\varphi_{1}\right)-\frac{e+x}{2}-\frac{c^{2}-b^{2}-d^{2}+2 \cdot b \cdot d \cdot \cos \theta}{2 \cdot(e+x)}\right] .
$$

Знайдемо $\varphi_{2}$ :

$$
\varphi_{2}=\arccos \left\{\frac{1}{b}\left[a-\mathrm{d} \cdot \cos \left(\theta-\varphi_{1}\right)-\frac{e+x}{2}-\frac{c^{2}-b^{2}-d^{2}+2 \cdot b \cdot d \cdot \cos \theta}{2 \cdot(e+x)}\right]\right\} .
$$

Синхронний рух щелеп забезпечується важелем. Умову синхронного (симетричного) руху лівої та правої щелепи можна записати як $\varphi_{1}=\varphi_{2}=\varphi$. Моделювання руху щелеп показало, що ці кути змінюються в діапазоні від $90^{\circ}$ до $150^{\circ}$. Максимальне розкриття щелеп становить 1720 мм.

Проведемо силовий аналіз сортувального грейфера. Він приводиться в дію від гідроциліндру, максимальне зусилля яке він розвиває становить $F=400$ кН. В точках $A$ і $B$ шарнірного з'єднання гідроциліндра з щелепами прикладаємо горизонтально це зусилля (рис. 5). Внаслідок цього щелепи обертаються та одночасно переміщується важіль, який перерозподіляє зусилля. На шарнірно підвішений важіль діють сили $T$, а на ножах щелеп при зачерпуванні або удержанні вантажу виникають зусилля $R$. 


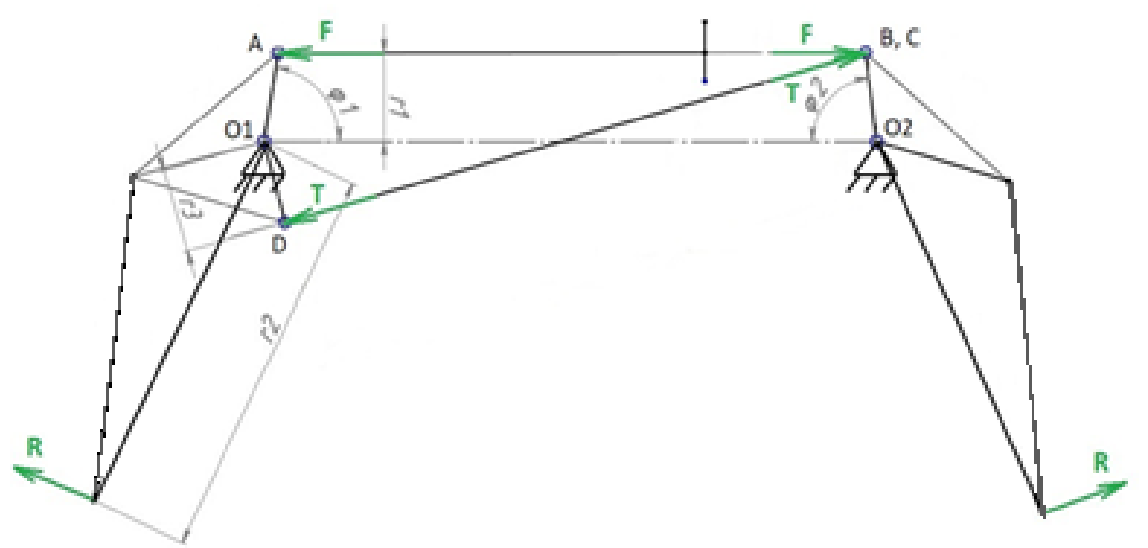

Puс. 5. Розрахункова схема грейферного механізму

Використовуючи принцип можливих переміщень, обчислено і побудовано графік залежності зусиль на ножах щелеп $R$ та зусиль $T$ виникаючих в важелі від кутового переміщення $\varphi$ (рис. 6 ).

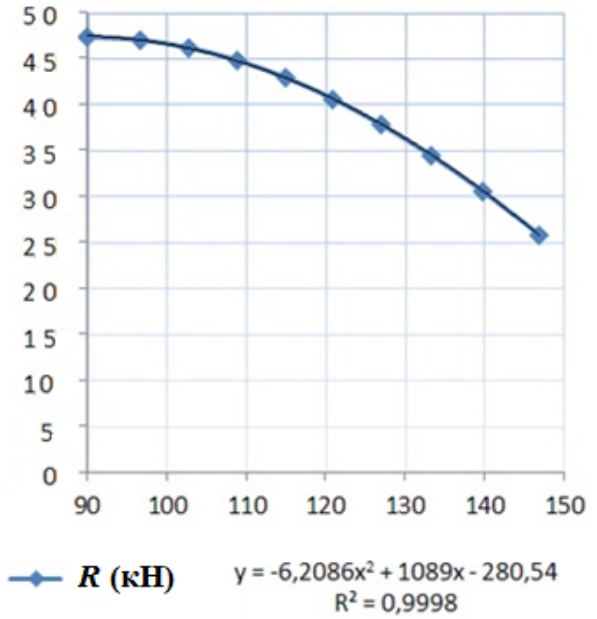

a)

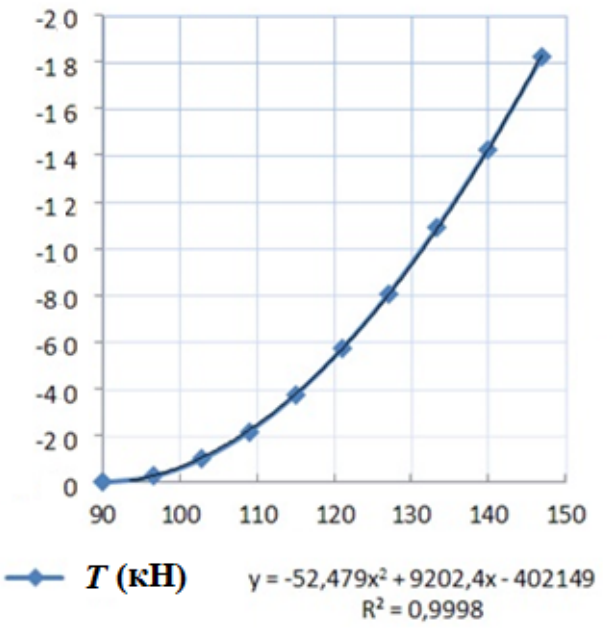

б)

Puc. 6. Залежність зусиль на ножах щелеп $R$ та у важелі $T$ від кута $\varphi$

Аналіз залежностей 6 дозволяє визначити діапазон зміни значень зусиль на ножах щелеп, що становить від 25 кН до 47 кН, та діапазоні значень зусиль на важелі становить від 0 до 180 кН. Характер залежностей нелінійний, його можна описати поліноміальною функцією другого ступеня, що наведена на рис. 6.

Розроблену тривимірну модель конструкції ковша грейфера та отримані значення зусиль використаємо для розрахунку напружень та деформацій в елементах металоконструкції ковшапри вертикальному і горизонтальну положеннях стріли екскаватора під дією ваги захопленого вантажу та під час захоплення матеріалу між ножами щелеп.

Розрахунки виконано методом скінчених елементів в SolidWorksSimulation (рис. 7), які показали, що в зімкнутому стані щелеп максимальні напруження локалізовані в місцях приварювання вушок та ребер до осей щелеп, у вушках, що передають зусилля від гідроциліндра. Максимальні значення напруження перевищують 500 МПа при межі плинності матеріалу 600 МПа. Локалізація максимальних напружень збігається 3 місцями виявлення тріщин та деформацій конструкцій при експлуатації. Це свідчить о високій якості побудованої розрахункової моделі, яку можна далі використати для розробки конструктивних рішень щодо усунення виниклих недоліків, визначення оптимальних параметрів підкріплення ковша грейфера. 


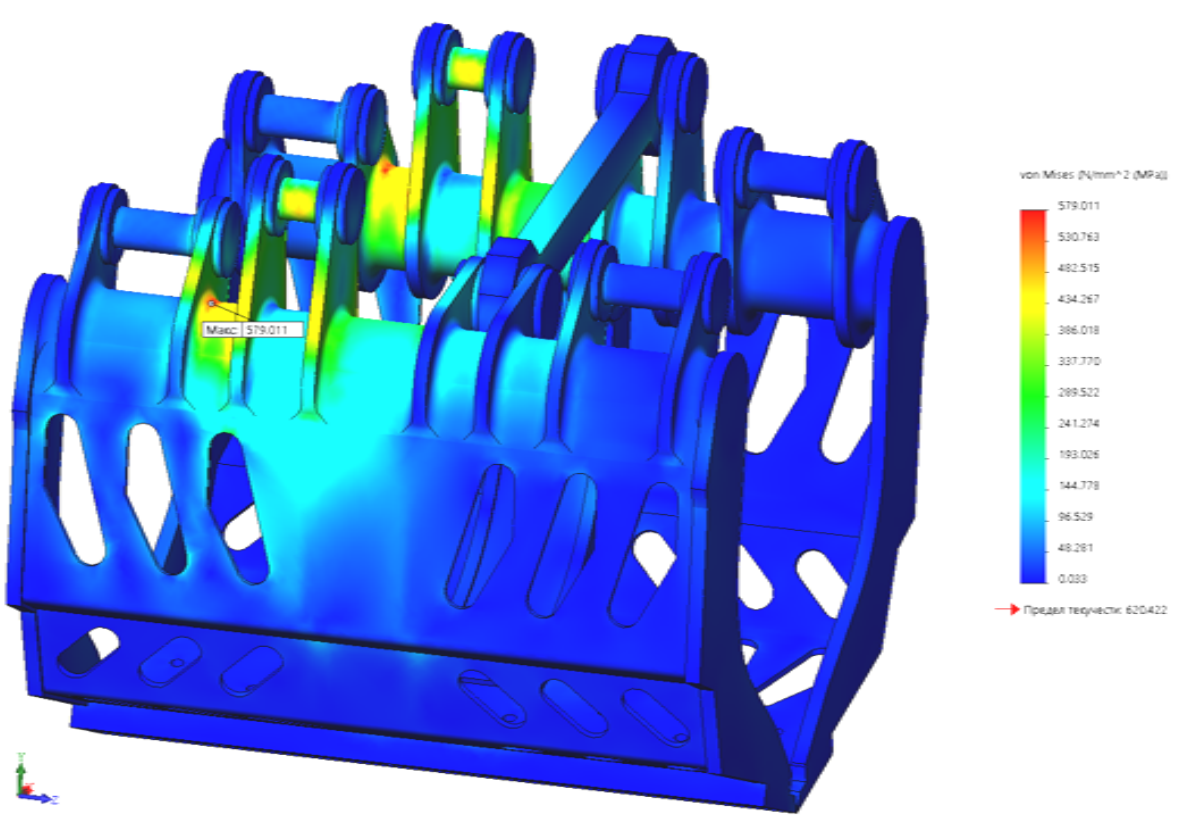

Рuc. 7. Графік напружень у зімкнутому стані

\section{Висновки}

В роботі розроблено розрахункову модель гідравлічного сортувального грейфера 3 двома щелепами, що може бути використана для силового, кінематичного аналізу, розрахунку на міцність.

Аналіз напружено-деформованого стану грейфера в різних положеннях дозволив виявити місця найбільших деформацій, які локалізовані в елементах, що передають зусилля від гідроциліндру на вісь щелеп. Результати розрахунків збігаються з даними експлуатації.

\section{Список використаної літератури}

1. Гебель Е.С., Джомартов А.А. Кинематический анализ многозвенного рычажного грейферного механизма. Известия Самарского научного иентра РАН. 2017. № 1-2. С. 216-219.

2. Гебель Е.С., Солонин Е.В. Моделирование как инструмент изучения дисциплины «Теория механизмов и машин». Компьютерные инструменты в образовании. 2008. № 5. С. 37-44.

3. Добрачев А. А., Раевская Л.Т., Швец А.В. Кинематические схемы, структуры и расчет параметров лесопромышленных манипуляторных машин : монография. Екатеринбург: УГЛТУ, 2014. $128 \mathrm{c}$.

4. Ackerman P., Pulkki R., Gleasure E. Modelling of wander ratios, travel speeds and productivity of cable and grapple skidders in softwood sawtimber operations in South Africa. Southern Forests. 2014. Vol. 76 No 2. pp. 101-110.

5. Zhou Yi Jun, Wang Kan. Modeling and Simulation of Hydraulic Excavator Based on Virtual Prototype. Advanced Materials Research. 2013., Vol. 785-786, pp. 1147-1150.

6. L. Tian, W. Zhang and H. Wang. Study on finite element method of power working device of hydraulic excavator. Proceedings of 2011 International Conference on Electronic \& Mechanical Engineering and Information Technology. 2011. Vol 8. pp. 4216-4219. 


\title{
WORK SIMULATION OF THE SORTING HYDRAULIC GRAB BUCKET Moskalova T, Polushyna M, Kasyanova A.
}

\begin{abstract}
The design and principle of operation of the sorting hydraulic grab bucket have been studied in the article. Kinematic and force analysis of the grab bucket design has been carried out.

The sorting hydraulic grabs are designed to perform a wide range of tasks related to moving and loading stone, backfilling and excavation, overloading objects of different shapes, volumes and hardness, and other sorting and dismantling operations.

Some shortcomings of hydraulic sorting grab design have been revealed while operating: the curving of the jaw support and lugs, which hold the hydraulic cylinder; cracks in welds. Such deformations of structure make it impossible to use the bucket. Therefore, the aim of this work is to identify the causes of breakages and develop the methods of eliminating the drawbacks of the structure of the sorting hydraulic grab bucket by analyzing the stress-strain state under the workloads.

For this purpose, a three-dimensional model of the grab bucket was developed, which allowed to carry out a kinematic analysis of the movement of the jaws and force analysis of the grab bucket under the action of the hydraulic cylinder. The developed model of the grab bucket and the obtained values of forces were used to calculate stresses and deformations of the grab bucket elements at vertical and horizontal positions of the power shovel boom under the cargo weight and forces, caused by material captured between jaw knives. The calculations, performed by the finite element method in SolidWorks Simulation, showed that in the closed state the maximum stresses in the structure are localized in the places, where the lugs and ribs are welded to the axes of the jaws, and in the lugs that transmit force from the cylinder. The localization of the maximum stresses coincides with the places of crack detection and deformations of the structure during operation. This indicates the high quality of the built model.

The computational model of the sorting hydraulic grab bucket with two jaws can be used for force and kinematic analysis, strength calculation, and for the development of constructive decisions concerning the elimination of the drawbacks of the structure, the definition of optimum parameters of reinforcement of the grab bucket.
\end{abstract}

\section{References}

[1] Gebel, Ye.S. \& Dzhomartov, A.A. (2017). Kinematicheskiy analiz mnogozvennogo greyfernogo mekhanizma [Kinematic analysis of a multi-link clamshell linkage]. Izvestiya Samarskogo nauchnogo tsentra - Bulletin of the Samara Scientific Center of the Russian Academy of Science, 1-2, 216-219 [in Russian].

[2] Gebel, Ye.S. \& Solonin, Ye.V. (2008). Modelirovanie kak instrument izucheniya distsipliny "Teoriya mashin i mechnizmov" [Modeling as a tool for studying the discipline "Theory of Mechanisms and Machines"]. Kompiutenye instrumenty $v$ obrazovanii - Computer tools in education, 5, 37-44 [in Russian].

[3] Dobrachev, A.A, Raevskaya, L.T. \& Shvets, A.V. (2014). Kinematicheskie skhemy, struktury $i$ raschet parametrov lesopromyshlennykh manipulyatornykh mashin [Kinematic diagrams, structures and calculation of parameters of timber handling machines]. Ekaterinburg: UGLTU [in Russian].

[4] Ackerman P., Pulkki R., Gleasure E., (2014). Modelling of wander ratios, travel speeds and productivity of cable and grapple skidders in softwood sawtimber operations in South Africa. Southern Forests, 76(2), 101-110.

[5] Zhou Yi Jun, Wang Kan. (2013). Modeling and Simulation of Hydraulic Excavator Based on Virtual Prototype. Advanced Materials Research, 785-786, 1147-1150.

[6] L. Tian, W. Zhang and H. Wang, (2011). Study on finite element method of power working device of hydraulic excavator. Proceedings of 2011 International Conference on Electronic \& Mechanical Engineering and Information Technology, 8, 4216-4219. 